\title{
The Influence of Plasma Pretreatment on the Structure and Antimicrobial Properties of Knitted Fabrics Treated With Herbal EXTRACTS
}

\author{
Dragana Grujić $^{1}$; Aleksandar Savić ${ }^{1}$; Ljiljana Topalić-Trivunović ${ }^{1}$; Simona Jevšnik ${ }^{2}$; \\ Tatjana Rijavec ${ }^{3}$; Marija Gorjanc ${ }^{3}$ \\ ${ }^{1}$ University of Banja Luka, Faculty of Technology, Vojvode Stepe Stepanovića 73, \\ 78000 Banja Luka, Bosnia and Herzegovina \\ ${ }^{2}$ Istanbul Technical University, Textile Technologies and Design Faculty, İnönü Caddesi, \\ No: 65, Gümüşsuyu (34437) Beyoğlu, Istanbul, Turkey \\ ${ }^{3}$ University of Ljubljana, Faculty of natural sciences and engineering, Snežniška 5, \\ 1000 Ljubljana, Slovenia \\ e-mail: ${ }^{1}$ dragana.grujic@unibl.rs
}

\begin{abstract}
In this paper we examined the effect of plasma pretreatment on the structure and antimicrobial properties of knitted fabrics (100\% cotton, $100 \%$ bamboo and $50 \%$ cotton $/ 50 \%$ bamboo) treated with alcoholic herbal extracts of Achillea millefolium L. and Reynoutria japonica Houtt. The influence of water vapour plasma pretreatment on the surface functionalization or change of the structure of the knitted fabrics is evaluated with SEM. Antimicrobial properties of knitted fabrics treated with herbal extracts were tested on Escherichia coli, Staphylococcus aureus and Candida albicans by using the parallel streaking method (AATCC TM 147-2004). The degree of coloration was evaluated with CIELAB method and with stereomicroscope. It was found that the plasma pretreatment and processing with the herbal extract of Reynoutria japonica Houtt. had a positive impact on the antimicrobial activity of the knitted fabrics against Staphylococcus aureus.
\end{abstract}

\section{Introduction}

Fabrics dyed with extracts from herbal plants are favoured by sensitive people in the fight against various kinds of allergies caused by synthetic colours. This dyeing process is an ecologically clean technology and plant extracts used for this process are obtained from natural renewable resources $[1,2]$. Using scientific and engineering knowledge in the field of surface treatment of materials enables the development of new textile materials with advanced properties, i.e. with additional functionality [3]. The surface textile treatment by low temperature plasma technology is more and more popular as a surface modification technique $[4,5]$. Textile materials subjected to the plasma treatment undergo chemical and physical transformations associated with chemical changes in the surface layer, structural changes of the surface layer, and the changes in the physical properties of the surface layer. Plasma treatment of fibre and polymer surfaces results in the formation of new functional groups, such as $-\mathrm{OH},-\mathrm{C}=\mathrm{O}$, - $\mathrm{COOH}$, which affect fabric wettability as well as facilitate graft polymerisation which, in turn, affects liquid repellence of treated textiles and nonwovens [5]. This process offers numerous advantages over the conventional chemical processes (drastic reduction in pollutants and a corresponding cost reduction for effluent treatment) so it can be considered as an environmentally benign technology $[4,6]$. The low temperature plasma is a partially ionized gas with electron temperatures much higher than ion temperatures. The highenergy electrons and low-energy molecular species can initiate reactions in the plasma volume without excessive heat and substrate degradation. Low temperature plasma can be 
applied to textile processing because most textile materials are heat sensitive polymers. With this method, a large variety of chemically active functional groups can be incorporated into the textile surface. The results of this activity can be the improvement of wettability, adhesion of coatings, printability, induced hydro- and/or oleophobic properties, changing physical and/or electrical properties, cleaning or disinfection of fibre surfaces, etc. [7, 8]. For the textile dyeing we commonly used dye solutions that provide a good degree of coloration, antimicrobial and deodorizing properties, UV protection, etc. The colour of herbal extracts and their antimicrobial effect come from substances with a different chemical composition (anthocyanins, anthraquinones, flavonoids, etc.) $[9,10]$.

\section{$1 \quad$ Research Subject}

Due to the fact that the bioactive substances from plants may slow or prevent the growth of microorganisms, there is a growing interest to study their application in textile processing [1115]. However, the effect of water vapour plasma pretreatment on the structure and antimicrobial properties of knitted fabrics treated with alcoholic herbal extracts of Achillea millefolium L. and Reynoutria japonica Houtt. is not sufficiently explained in the literature. Hence, the aim of this paper is to present the benefits that came with the surface activation of knitted fabrics with water vapour plasma in a better absorption of alcoholic herbal extracts of Achillea millefolium and Reynoutria japonica, which could increase the antimicrobial activity of these fabrics.

\section{$2 \quad$ Materials and Methods}

Three different kinds of fabrics were used with the same constructional characteristics and roughly with the same surface mass. They were made from two kinds of yarn, whose main characteristics are given in Tab. 1. The basic characteristics of the knitted fabrics are given in Tab. 2, and the research model is in Fig. 1.

Tab. 1: Basic characteristics of the used yarn

\begin{tabular}{|l|c|c|c|c|}
\hline Type of yarn & $\begin{array}{c}\text { Mass per length } \\
{[\mathbf{t e x}]}\end{array}$ & $\begin{array}{c}\text { Breaking strength } \\
{[\mathbf{c N}]}\end{array}$ & $\begin{array}{c}\text { Elongation at break } \\
{[\mathbf{\%}]}\end{array}$ & $\begin{array}{c}\text { Twisting } \\
{\left[\mathbf{m}^{-\mathbf{1}}\right]}\end{array}$ \\
\hline PAMUK & 28.86 & 148.2 & 2.71 & 642.8 \\
\hline BAMBUS & 30.16 & 174.5 & 7.59 & 206.8 \\
\hline
\end{tabular}

Source: Own

Tab. 2: Basic characteristics of the knitted fabrics

\begin{tabular}{|l|c|c|c|c|l|}
\hline \multirow{2}{*}{$\begin{array}{c}\text { Code of } \\
\text { fabrics }\end{array}$} & \multirow{2}{*}{$\begin{array}{c}\text { Type of } \\
\text { weaves }\end{array}$} & $\begin{array}{c}\text { Mass per unit weight } \\
{\left[\mathbf{g} / \mathbf{m}^{\mathbf{2}}\right]}\end{array}$ & \multicolumn{2}{|c|}{$\begin{array}{c}\text { Density } \\
{\left[\mathbf{c m}^{-\mathbf{1}}\right]}\end{array}$} & \multicolumn{2}{|c|}{$\begin{array}{c}\text { Raw material } \\
\text { composition }\end{array}$} \\
\cline { 4 - 5 } & SO & 111.89 & 17 & 17 & $100 \%$ cotton \\
\hline BAM & Singl & 117.60 & 17 & 17 & $100 \%$ bamboo \\
\hline CO/BAM & Singl & 109.15 & 17 & 17 & $\begin{array}{l}50 \% \text { cotton, } \\
50 \% \text { bamboo }\end{array}$ \\
\hline
\end{tabular}

Source: Own 


$\begin{aligned} & \text { UNTREATED AND PLASMA TREATED KNITTED FABRICS } \\ & \begin{array}{c}100 \% \text { Cotton } \\ (\mathrm{CO})\end{array}\end{aligned}$
$\begin{gathered}100 \% \text { Bamboo } \\ \text { (BAM) }\end{gathered}$
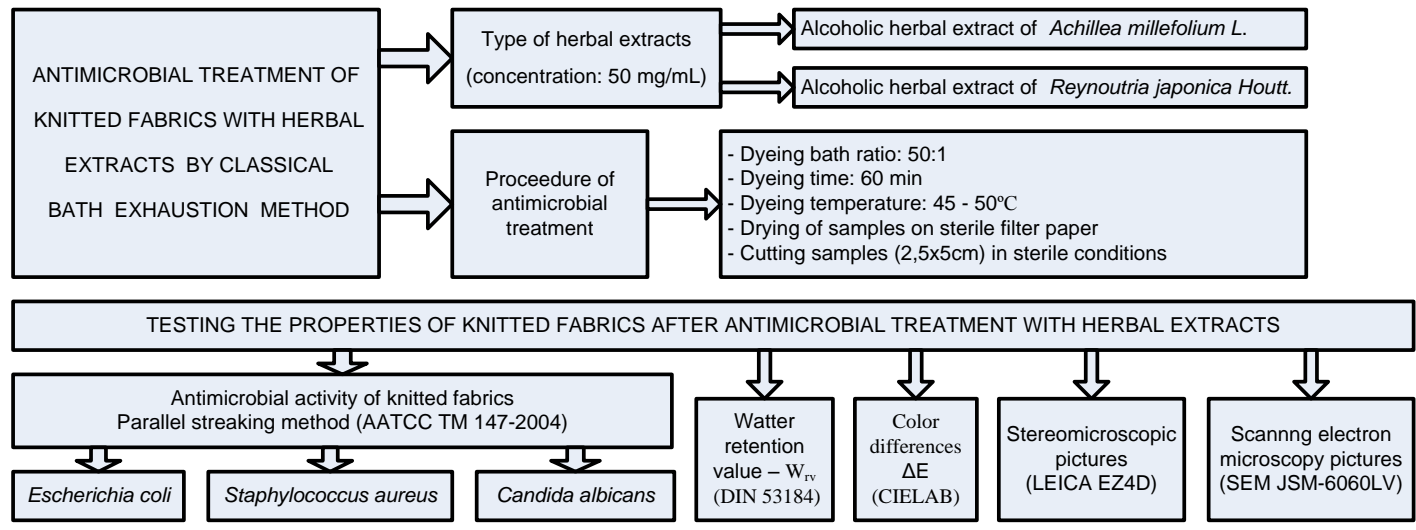

Source: Own

Fig. 1: Research model

The research model is shown in Figure 1, including the information on the tested knitted fabrics which were treated with alcoholic herbal extracts of Achillea millefolium L. and Reynoutria japonica Houtt. (extracts concentrations - $50 \mathrm{mg} / \mathrm{mL}$ ) by the classical bath exhaustion method. Sorption properties of the knitted fabrics were determined by measuring the water retention value, before and after processing them with herbal extracts. The degree of coloration of differently processed knitted fabrics was evaluated on the basis of stereomicroscopic pictures and the CIELAB method. The influence of water vapour plasma pretreatment on the surface functionalization or change of the structure of the knitted fabrics was evaluated with SEM. Antimicrobial properties of the knitted fabrics treated with herbal extracts were tested on Escherichia coli, Staphylococcus aureus and Candida albicans by using the parallel streaking method.

\subsection{Sorption properties of the knitted fabrics}

The water retention value of the raw and water vapour plasma treated knitted fabrics, as a parameter of sorption properties, was determined before and after the treatment with alcoholic herbal extracts of Achillea millefolium L. and Reynoutria japonica Houtt. Determination of the water retention value in the knitted fabrics WRV (\%) by the centrifugation method was performed according to the standard DIN 53814 [16]. Water retention value in the knitted fabrics WRV (\%) was calculated according to formula (1):

$$
W_{r v}=\frac{m_{c}-m_{k l}}{m_{k l}} \cdot 100
$$

where:

$m_{c}$ is the mass of the centrifugated sample [g],

$m_{k i}$ is the mass of the conditioned sample [g].

\subsection{Stereomicroscopic pictures and spectrophotometric analysis of samples}

To notice the changes in the surface structure and the degree of coloration of differently processed knitted fabrics treated with alcoholic herbal extracts of Achillea millefolium L. and Reynoutria japonica Houtt. the device LEICA EZ4D was used on 30X zoom to make stereomicroscopic recordings. 
The degree of coloration of the knitted fabrics was analyzed with the spectrophotometer CM$2600 \mathrm{~d} / 2500 \mathrm{~d}$ before and after water vapour plasma treatment, before and after processing with alcoholic herbal extracts of Achillea millefolium L. and Reynoutria japonica Houtt. On the basis of the measured parameters CIE L*a* $\mathrm{b} *$, the value of difference in color was determined by equation (2):

$$
\Delta E=\sqrt{\Delta L^{* 2}+\Delta a^{* 2}+\Delta b^{* 2}},
$$

where $L^{*}$ is chrominance and $a^{*}$ and $b^{*}$ are coordinates.

On the basis of the results obtained for $\Delta E$ it was determined what difference of color reproduction can be observed when comparing the knitted fabrics treated with alcoholic herbal extracts of Achillea millefolium L. and Reynoutria japonica Houtt. to the initial sample (untreated knitted fabrics and knitted fabrics treated with water vapour plasma).

\subsection{Investigation of antimicrobial activity}

Antimicrobial activity of alcoholic herbal extracts of Achillea millefolium L. and Reynoutria japonica Houtt. with respect to Escherichia coli and Staphylococcus aureus as well as yeast Candida albicans, was tested by the parallel streaking method (AATCC TM 147) [17].

The concentration of bacteria and yeast was $0.5 \mathrm{McFarland}$ standard.

After incubation, zones of inhibition were measured from equation (3):

$$
Z i=(T-D) / 2(\mathrm{~mm})
$$

where:

$Z i$ - width of zone of inhibition,

$T$ - width of sample + zone of inhibition,

$D$ - width of sample (mm).

If there is no zone of inhibition, and no growth below the sample, then it is defined as contact inhibition.

\section{$3 \quad$ Results and discussion}

Water retention values $\left(W_{r v}\right)$ and stereomicroscopic pictures of untreated, plasma pretreated knitted fabrics and knitted fabrics treated with alcoholic herbal extracts are given in Tables 3 and 4.

Tab. 3: Watter retention value $-W_{r v}(\%)$

\begin{tabular}{|l|c|c|c|}
\hline \multirow{2}{*}{ Treatment of knitted fabrics } & \multicolumn{3}{|c|}{ Type of knitted fabrics } \\
\cline { 2 - 4 } & CO & BAM & CO/ BAM \\
\hline Without pretreating (untreated) & 34.89 & 70.20 & 55.84 \\
\hline Pretreated with plasma of water vapour (plasma) & 34.86 & 71.60 & 52.97 \\
\hline Untreated + extract Achillea millefolium & 28.50 & 63.81 & 43.83 \\
\hline Plasma pretreated + extract Achillea millefolium & 22.34 & 48.93 & 39.07 \\
\hline
\end{tabular}

Source: Own 
Tab. 4: Stereomicroscopic pictures of untreated, plasma pretreated knitted fabrics and those treated with alcoholic extracts of Achillea millefolium L. and Reynoutria japonica Houtt.

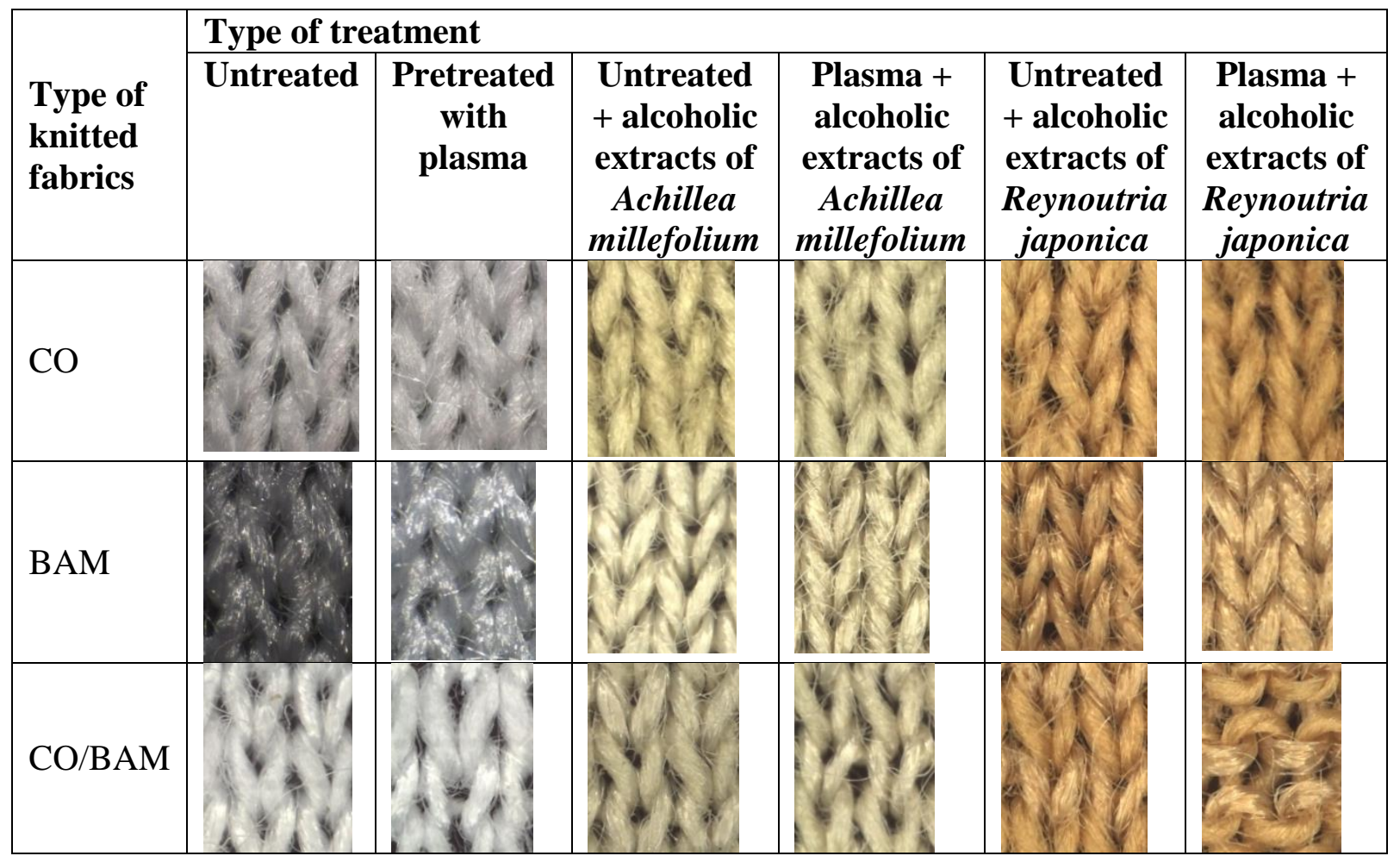

Source: Own

Scanning electron microscopy pictures of untreated, plasma pretreated and knitted fabrics treated with alcoholic herbal extracts of Achillea millefolium are shown in Figures 2-4.

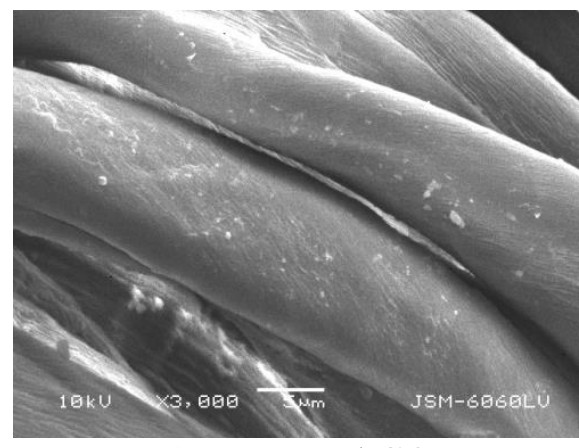

a) Untreated $\mathrm{CO}$

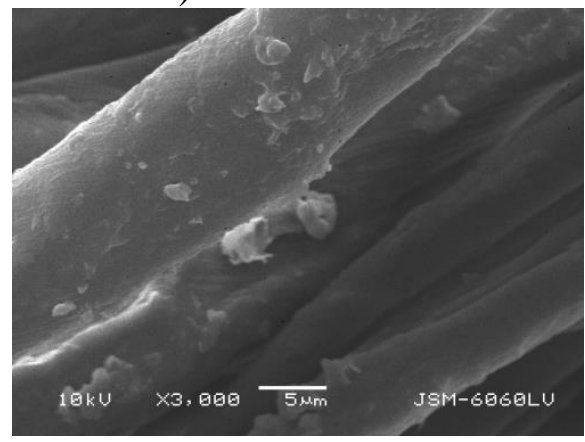

c) Untreated $\mathrm{CO}+$ alcoholic extract

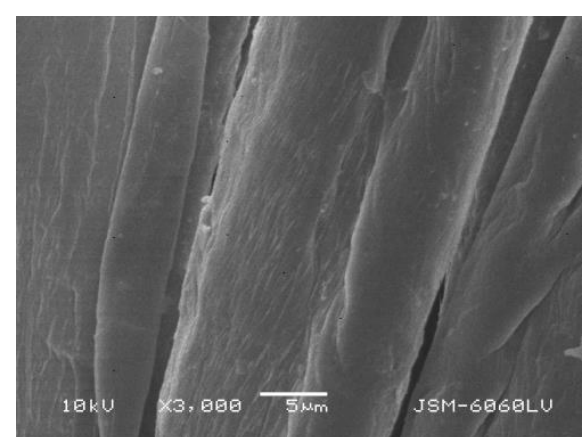

b) $\mathrm{CO}$ pretreated with plasma

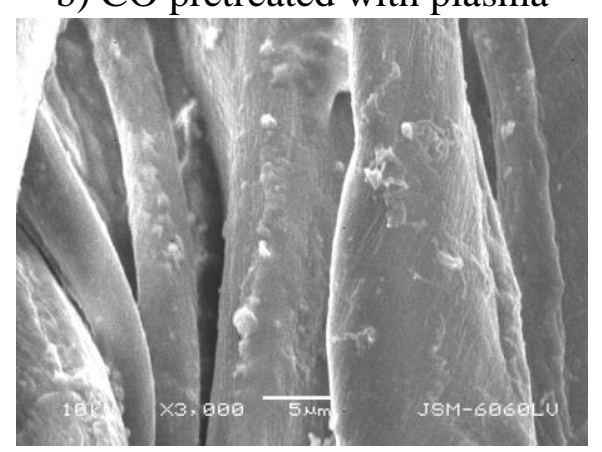

d) $\mathrm{CO}$ pretreated with plasma + alcoholic extract

Source: Own

Fig. 2: SEM pictures of CO untreated, plasma pretreated and treated with alcoholic herbal extracts of Achillea millefolium $L$. 


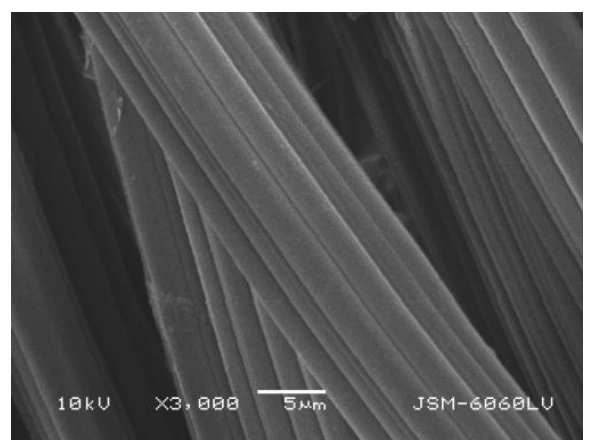

a) Untreated BAM

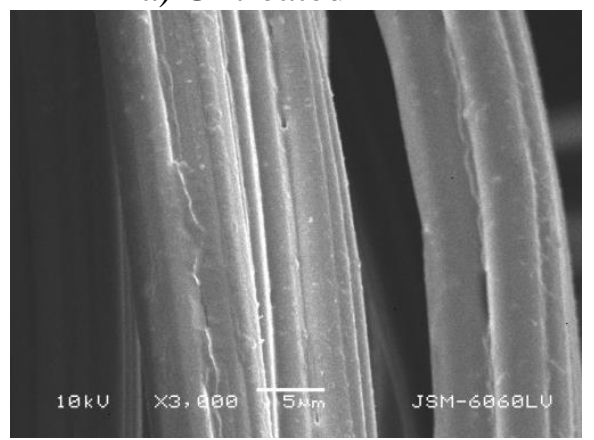

c) Untreated BAM + alcoholic extract Source: Own

Fig. 3: SEM pictures of BAM untreated, plasma pretreated and treated with alcoholic herbal extracts of Achillea millefolium $L$.

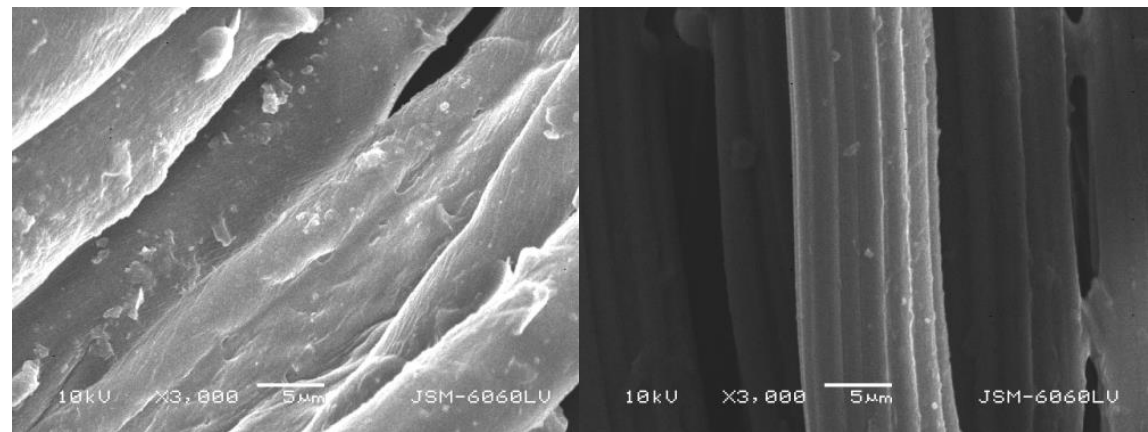

a) Untreated $\mathrm{CO} / \mathrm{BAM}+$ alcoholic extract

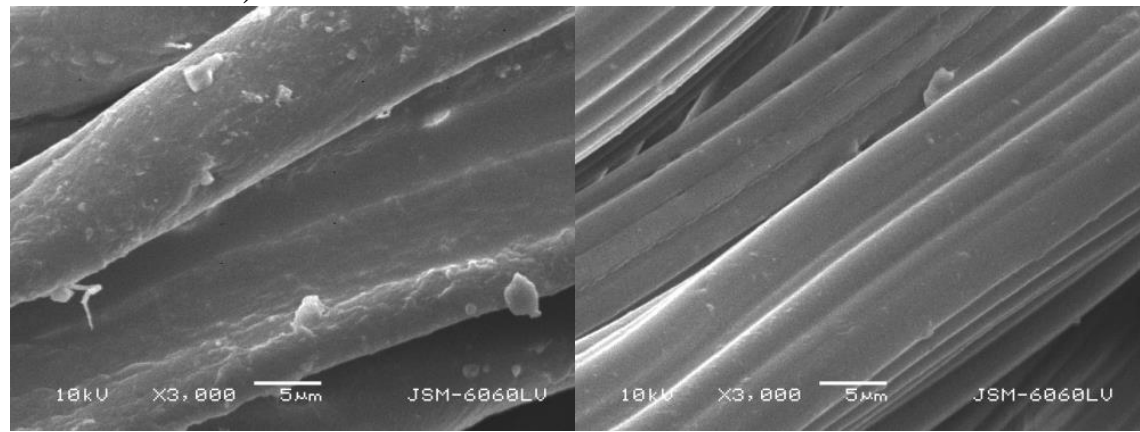

b) $\mathrm{CO} / \mathrm{BAM}$ pretreated with plasma + alcoholic extract

Source: Own

Fig. 4: SEM pictures of CO/BAM untreated and plasma pretreated + alcoholic extracts of Achillea millefolium $L$.

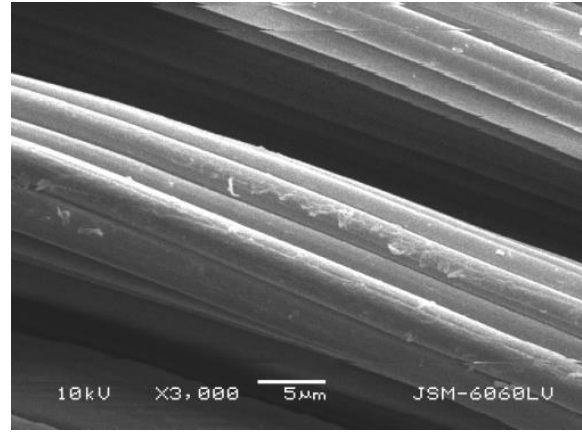

b) BAM pretreated with plasma

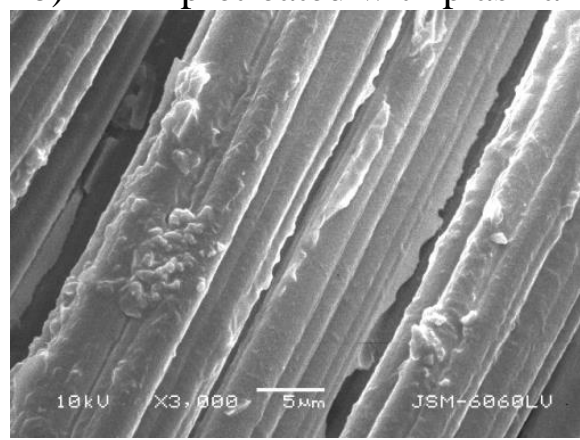

d) BAM pretreated with plasma + alcoholic extract 
Tab. 5: Antimicrobial treatments of knitted fabrics with alcoholic herbal extracts

\begin{tabular}{|c|c|c|c|c|c|c|c|}
\hline \multirow{2}{*}{\multicolumn{2}{|c|}{ Treatment }} & \multicolumn{2}{|c|}{ CO } & \multicolumn{2}{|c|}{ BAM } & \multicolumn{2}{|c|}{ CO/BAM } \\
\hline & & untreated & plasma & untreated & plasma & untreated & plasma \\
\hline \multirow[t]{3}{*}{$\begin{array}{l}\text { Achillea } \\
\text { millefolium }\end{array}$} & $\begin{array}{l}\text { Staphylococcus } \\
\text { aureus }\end{array}$ & KI & KI & $\mathrm{Zi}=3.44$ & $\mathrm{Zi}=1.50$ & $\mathrm{KI}$ & KI \\
\hline & Escherichia coli & NA & NA & NA & NA & NA & KI \\
\hline & $\begin{array}{l}\text { Candida } \\
\text { albicans }\end{array}$ & NA & NA & NA & NA & NA & NA \\
\hline \multirow{3}{*}{$\begin{array}{l}\text { Reynoutria } \\
\text { japonica }\end{array}$} & $\begin{array}{l}\text { Staphylococcus } \\
\text { aureus }\end{array}$ & $\mathrm{Zi}=0.32$ & $\mathrm{Zi}=0.6$ & $\mathrm{Zi}=0.65$ & $\mathrm{Zi}=0.72$ & $\mathrm{Zi}=0.50$ & $\mathrm{KI}$ \\
\hline & Escherichia coli & NA & NA & NA & NA & NA & NA \\
\hline & $\begin{array}{l}\text { Candida } \\
\text { albicans }\end{array}$ & NA & NA & NA & NA & $\mathrm{NA}$ & NA \\
\hline
\end{tabular}

Source: Own

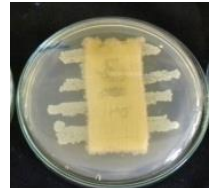

a) S. aureus

(KI)

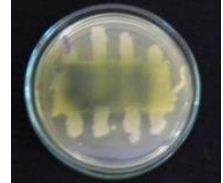

b) E. coli

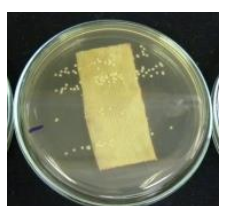

c) C. albicans

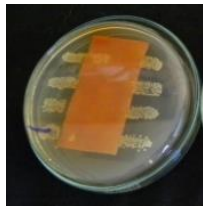

d) S. aureus

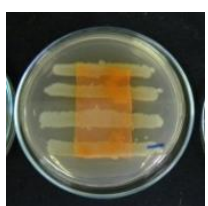

e) E.coli

(no activity) (no activity)

Source: Own

(no activity)

(no activity)

$(\mathrm{Zi}=0.60)$

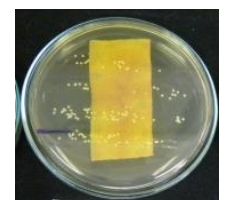

f) C. albicans

Fig. 5: Antimicrobial treatments of $\mathrm{CO}$ with herbal extracts of Achillea millefolium L. and Reynoutria japonica Houtt.

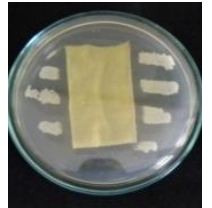

a) S. aureus

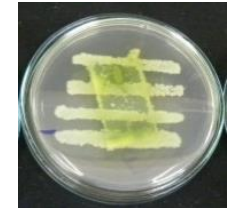

b) E. coli

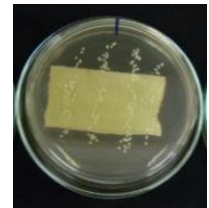

c) C. albicans

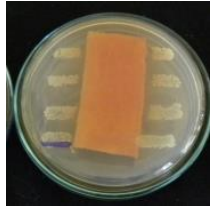

d) S. aureus

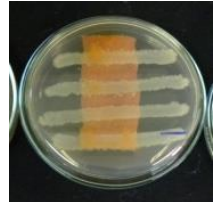

e) E.coli

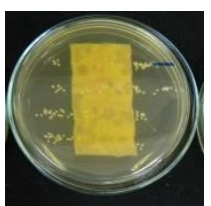

f) C. albicans

$(\mathrm{Zi}=3.44)$

Source: Own

(no activity) (no activity) $\quad(\mathrm{Zi}=0.72)$

(no activity)

(no activity)

Fig. 6: Antimicrobial treatments of BAM with herbal extracts of Achillea millefolium L. and Reynoutria japonica Houtt.

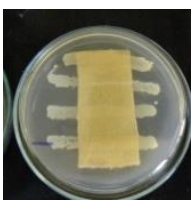

a) S. aureus

(KI)

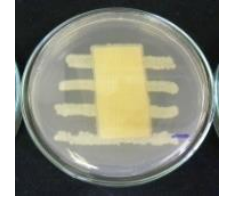

b) E. coli

(KI)

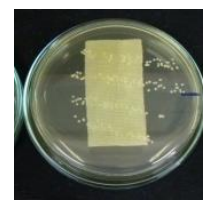

c) C. albicans d) S. aureus

(no activity) $\quad(\mathrm{Zi}=0.50)$

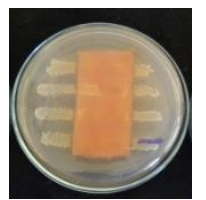

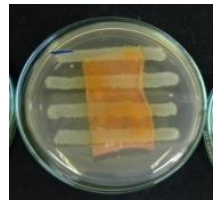

e) E.coli

(no activity)

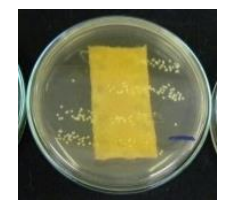

f) C. albicans

(no activity)

Source: Own

Fig. 7: Antimicrobial treatments of CO/BAM with herbal extracts of Achillea millefolium L. and Reynoutria japonica Houtt.

Antimicrobial activity of the knitted fabrics treated with alcoholic herbal extracts of Achillea millefolium L. and Reynoutria japonica Houtt. are shown in Table 5, and Figures 5-7 present examples of antimicrobial activity tests. 
Tab. 6: Colour differences between the untreated, plasma pretreated and the knitted fabrics treated with a herbal extract of Achillea millefolium L. and Reynoutria japonica Houtt.

\begin{tabular}{|c|c|c|c|c|c|}
\hline $\begin{array}{l}\text { Type of } \\
\text { knitted } \\
\text { fabrics }\end{array}$ & Treatment & $L$ & $a$ & $b$ & $\Delta E$ \\
\hline \multirow{11}{*}{$\mathrm{CO}$} & untreated & 97.39 & 2.17 & -9.30 & I \\
\hline & plasma & 96.99 & 1.94 & -8.73 & 0.734 \\
\hline & untreated + extract Achillea millefolium & 67.24 & -3.66 & 28.58 & 48.77 \\
\hline & untreated + extract Reynoutria japonica & 70.65 & 12.25 & 51.71 & 67.37 \\
\hline & plasma & 96.99 & 1.94 & -8.73 & I \\
\hline & plasma + extract Achillea millefolium & 74.02 & -2.35 & 29.12 & 44.48 \\
\hline & plasma + extract Reynoutria japonica & 69.41 & 13.21 & 54.30 & 69.71 \\
\hline & untreated + extract Achillea millefolium & 67.24 & -3.66 & 28.58 & 1 \\
\hline & plasma + extract Achillea millefolium & 74.02 & -2.35 & 29.12 & 6,93 \\
\hline & untreated + extract Reynoutria japonica & 70.65 & 12.25 & 51.71 & I \\
\hline & plasma + extract Reynoutria japonica & 69.41 & 13.21 & 54.30 & 3,02 \\
\hline \multirow{11}{*}{ BAM } & untreated & 96.27 & 1.87 & -5.73 & 1 \\
\hline & plasma & 96.34 & 1.61 & -6.11 & 0,464 \\
\hline & untreated + extract Achillea millefolium & 77.93 & -1.53 & 22.08 & 33.49 \\
\hline & untreated + extract Reynoutria japonica & 71.40 & 12.78 & 41.99 & 54.90 \\
\hline & plasma & 96.34 & 1.61 & -6.11 & 1 \\
\hline & plasma + extract Achillea millefolium & 72.80 & -0.768 & 28.23 & 41.71 \\
\hline & plasma + extract Reynoutria japonica & 71.83 & 11.91 & 41.28 & 54.34 \\
\hline & untreated + extract Achillea millefolium & 77.93 & -1.53 & 22.08 & 1 \\
\hline & plasma + extract Achillea millefolium & 72.80 & -0.768 & 28.23 & 8,04 \\
\hline & untreated + extract Reynoutria japonica & 71.40 & 12.78 & 41.99 & I \\
\hline & plasma + extract Reynoutria japonica & 71.83 & 11.91 & 41.28 & 1.20 \\
\hline \multirow{11}{*}{ CO/BAM } & untreated & 96.73 & 2.12 & -8.80 & 1 \\
\hline & plasma & 96.64 & 1.88 & -8.36 & 0.503 \\
\hline & untreated + extract Achillea millefolium & 79.40 & -1.94 & 24.32 & 37.60 \\
\hline & untreated + extract Reynoutria japonica & 71.27 & 13.00 & 46.55 & 61.89 \\
\hline & plasma & 96.64 & 1.88 & -8.36 & 1 \\
\hline & plasma + extract Achillea millefolium & 77.71 & -0.217 & 30.72 & 43.48 \\
\hline & plasma + extract Reynoutria japonica & 72.02 & 11.66 & 44.15 & 58.82 \\
\hline & untreated + extract Achillea millefolium & 79.40 & -1.94 & 24.32 & 1 \\
\hline & plasma + extract Achillea millefolium & 77.71 & -0.217 & 30.72 & 6.84 \\
\hline & untreated + extract Reynoutria japonica & 71.27 & 13.00 & 46.55 & I \\
\hline & plasma + extract Reynoutria japonica & 72.02 & 11.66 & 44.15 & 2.85 \\
\hline
\end{tabular}

Source: Own

Water retention value $\left(W_{r v}\right)$ as a parameter of sorption properties was not significantly changed after plasma pretreatment. However, the test results of $W_{r v}$ after the treatment with alcoholic extract of Achillea millefolium L. indicate that there was a large reduction in $W_{r v}$ in the knitted fabrics pretreated with plasma compared to the untreated ones (Table 3). This has confirmed that the surface modification with plasma enabled binding larger amounts of particles from alcoholic herbal extracts and thus reduced the number of groups capable of binding water. This is especially conspicuous in BAM, where the $W_{r v}$ for plasma pretreated 
samples decreased from $71.60 \%$ to $48.93 \%$ after treatment with the alcoholic extract of Achillea millefolium L.

Stereomicroscopic pictures showed that the plasma pretreatment mainly affected the degree of coloration for the fabrics treated with alcoholic extracts of Achillea millefolium L. and Reynoutria japonica Houtt. The only exception is plasma pretreated BAM, where the degree of coloration increased after the treatment with the alcoholic extract of Achillea millefolium L. (Table 4).

The SEM image of untreated cotton (Figure 2a) showed a typical grooved surface morphology with microfibrils oriented predominantly in the direction of the fiber axis. The outlines of the macrofibrils are still visible, and they are smooth and distinct due to the presence of an amorphous layer covering the fibre [8]. The surface of the water vapour plasma pretreated cotton is striped and cleaned, and a more distinct macrofibrilar structure is obtained (Figure 2b). From the SEM picture of BAM it is obvious that the plasma pretreatment changed the surface structure in comparison to the untreated one (Figure $3 b$ ). When cotton and bamboo knitted fabrics were pretreated with water vapour plasma, the quantity of the adsorbed particles of alcoholic extracts of Achillea millefolium L. was enlarged (Figures $2 \mathrm{~d}, 3 \mathrm{~d}, 4 \mathrm{a}$ and $4 \mathrm{~b}$ ). The results showed that plasma pretreatment heavily modified the morphology, surface and chemical properties of the knitted fabrics and they had an impact on the absorption of alcoholic herbal extracts into the knitted fabrics.

The investigation of the antimicrobial activity of the knitted fabrics treated with alcoholic herbal extracts of Achillea millefolium L. and Reynoutria japonica Houtt. against bacteria Staphylococcus aureus and Escherichia coli and yeast Candida albicans (Table 5) showed that the plasma pretreatment had an influence on the inhibition zones against Staphylococcus aureus for the knitted fabrics CO and BAM treated with the alcoholic extract of Reynoutria japonica Houtt. For the knitted fabrics CO/BAM only a contact inhibition was observed, i.e. there was no increase in the inhibition zones when comparing with $\mathrm{CO}$ and BAM. This can be connected with colour differences (Table 6), where it can be seen that in the knitted fabrics CO/BAM plasma pretreated and treated with the alcoholic extract of Reynoutria japonica Houtt. the degree of coloration was lower $(\Delta E=58.82)$ when compared to the untreated one $(\Delta E=61.89$ ). It is known that the colour of herbal extracts and their antimicrobial effect come from substances with a different chemical composition (anthocyanins, anthraquinones, flavonoids, etc.) $[9,10]$. These substances in combination with plasma surface modification, which affected the ability of wetting and coloration, improved the antimicrobial activity of the knitted fabrics treated with alcoholic herbal extracts. The alcoholic extract of the plant rhizomes and related species exhibit the antimicrobial activity against a number of microorganisms, which is slightly more pronounced against the gram positive bacteria [18]. In addition to the growth inhibition, which is dependent on the concentration, the alcoholic extract of rhizomes of Reynoutria japonica Houtt. significantly reduces the number of individual species of microorganisms [19]. Gram-negative bacteria are resistant to plant extracts due to the activity of efflux pumps [20], and the sensitivity of Escherichia coli in this experiment is smaller. Other studies have confirmed the sensitivity of Staphylococcus aureus and other Gram-positive bacteria against the alcoholic extract of Achillea millefolium L. [21, 22], yeast Candida albicans is poorly sensitive to most plant extracts [23].

\section{Conclusion}

The effect of plasma pretreatment on the structure and antimicrobial properties of the knitted fabrics treated with alcoholic herbal extracts of Achillea millefolium L. and Reynoutria 
japonica Houtt. is presented with SEM pictures, water retention values, colour differences and inhibition zones. It can be concluded that:

- Plasma pretreatment had an effect on the reduction of sorption properties of the knitted fabrics treated with the alcoholic herbal extract of Achillea millefolium L. This pretreatment increased the zone of inhibition for the knitted fabric BAM against bacteria Staphylococcus aureus.

- In the treatment of the knitted fabrics with alcoholic herbal extract of Reynoutria japonica Houtt. it was possible to observe a positive effect of the plasma pretreatment on the antimicrobial properties. In the plasma pretreated knitted fabrics $\mathrm{CO}$ and BAM, the inhibition zone was increased against Staphylococcus aureus, but without any effect on Escherichia coli and Candida albicans.

- The degree of coloration was lower in the plasma pretreated knitted fabrics when compared to the untreated, and it was confirmed by measuring the colour differences. The differences in colour were acceptable for the knitted fabrics treated with the alcoholic herbal extract of Reynoutria japonica Houtt. because the value for $\Delta E$ ranged from 1.2 for BAM to 3.2 for CO (hardly perceptible differences). Significant colour differences $(\Delta E>6)$ were observed between the untreated and plasma pretreated samples and after treatment with the alcoholic extract of Achillea millefolium L., and the colour differences are not considered acceptable (not acceptable), i.e. the plasma pretreatment decreased the degree of coloration.

\section{Acknowledgements}

The research is supported by the Ministry of Science and Technology of Republic of Srpska, project number: 19/6-020/961-105/12 "Finishing of materials for sportswear in order to improve thermophysiological comfort" and a bilateral project number: 19/6-2020/961-12/13, "Exploring the effect of textiles with high-performances on comfort when wearing sportswear".

\section{Literature}

[1] GRUJIĆ, D.; SAVIĆ, A.; TOPALIĆ-TRIVUNOVIĆ, Lj.; JANJIĆ, S.; JEVŠNIK, S. et al.: (2013). Istraživanje uticaja sirovinskog sastava i načina obrade tkanina na njihova antibakterijska svojstva. Zbornik radova ,X Savjetovanje hemičara, tehnologa i ekologa Republike Srpske“ Banjaluka 2013, 398-409.

[2] LEE, L. H.; HWANG, E. K.; KIM, H. D.: (2009). Colorimetric Assay and Antibacterial Activity of Cotton, Silk, and Wool Fabrics Dyed with Peony, Pomegranate, Clove, Coptis chinenis and Gallnut Extracts. Materials. 2(1), 10-21.

[3] JOCIĆ, D.: (2013). Funkcionalizacija tekstilnih materijala primenom polimernih sistema osjetljivih na spoljne stimulanse. Savremene tehnologije. 2(2), 5-14.

[4] MORENT, R.; De GEYTER, N.; VERSCHUREN, J.; De CLERCK, K.; KIEKENS P. et al.: (2008). Non-thermal plasma treatment of textiles. Surface and Coatings Technology. 202, 3427-3449.

[5] SHISHOO, R.: (2007). Plasma technologies for textiles. Woodhead Publishing Limited in association with The Textile Institute (Cambridge).

[6] CARNEIRO, N.; SOUTO, A. P.; MARIMBA, A.; TENA, B.; FERREIRA, H. et al. (2001). Dyeability of CORONA treated fabric. Coloration Technology, 117, 298-302. 
[7] SUN, D.; STYLIOS, G. K.: (2006). Fabric surface properties affected by low temperature plasma treatment. Journal of Materials Processing Technology. 173, 172177.

[8] GORJANC, M.; GORENŠEK, M.; JOVANČIĆ, P.; MOZETIČ, M.: (2013). Multifunctional Textiles - Modification by Plasma, Dyeing and Nanoparticles, EcoFriendly Textile Dyeing and Finishing. (Dr. Melih Gunay ed.). InTech (Rijeka).

[9] ALI, S. I.: (1993). Revival of natural dyes in Asia. J. Soc. Dyers. Color. 109, 13-14.

[10] PRABHU, H. K.; BHUTE, S. A.: (2012). Plant based natural dyes and mordants: A Review. J. Nat. Prod. Plant Resour. 2(6), 649-664.

[11] JOSHI, M. S.; WAZED, Ali, S.; PURWAR, R.: (2009). Ecofriendly antimicrobial finishing of textiles using bioactive agents on natural product. Indian Journal of Fibre and Textile Research. 34, 295-304.

[12] GOUVEIA, C. I.: (2010). Nanobiotechology: A new strategy to develop non-toxic antimicrobial textiles. Current Research, Technology and education Topics in Applied Microbiology and Microbial Biotechnology. 407-414.

[13] SATHIANARAYANAN, M. P.; BHAT, N. V.; KOKATE, S. S.; WALUNJ, V. E.: (2010). Antibacterial finish for cotton fabric from herbal products. Indian Journal of Fibre \& Textile Research. 35, 50-58.

[14] MINGBO, M.; RONGXIA, L.; YANGYANG, D.; ZHIRONG, T.; WENLONG, Z.: (2013). Analysis of antibacterial properties of naturally colored cottons. Textile Research Journal. 83 (5), 462-470.

[15] GRUJIĆ, D.; SAVIĆ, A.; TOPALIĆ-TRIVUNOVIĆ, Lj.; JANJIĆ, S.: (2014). Textile processing with extract of the plant Yarrow (Achillea millefolium L.) in order to alleviate allergy from the sweat. Contemporary materials. 22, 305-317.

[16] DIN 53814 Bestimmung des Wasserrückhaltevermögens von Fasern und Fadenabschnitten. (1997).

[17] AATCC TM 147-2004: Antibacterial Activity Assessment of Textile Materials: Parallel Streak Method.

[18] KAWAI, Y.; SAWANO, R.; KUMAGAI, H.; YAMAZAKI, K.; SUZUKI, H. et al.: (2004). Antimicrobial activity of extracts from giant knotweed Polygonum sachalinense against animal pathogenic bacteria. Bull. Fish. Sci. Hokkaido Univ. 55(3), 139-144.

[19] PAVIČIĆ, S. S.; KUKRIĆ, Z. Z.; TOPALIĆ-TRIVUNOVIĆ, Lj.; DAVIDOVIĆ, A. N.; ŽABIĆ, M. M.: (2009). Antioksidativna i antimikrobna aktivnost ekstrakta Reynoutria japonica. Hemijska industrija. 63 (5), 427-432.

[20] TEGOS, G.; STERMITZ, F. R.; LOMOVSKAYA, O.; LEWIS, K.: (2002). Multidrug pump inhibitors uncover remarkable activity of plant antimicrobials. Antimicrobial Agents and Chemotherapy. 3133-3144.

[21] HASSON, N. R.: (2011). Antibacterial activity of water and alcoholic crude extract of flower Achillea millefolium. Rafidain Journal of Science. 22(3), 11-20.

[22] TAJIK, H.; JALALI, F. S. S.; Sobhani, A.; SHAHBAZI, Y.; ZADEH, M. S.: (2008). In vitro assessment of antimicrobial efficacy of alcoholic extract of Achillea millefolium in comparison with penicillin derivatives. Journal of Animal and Veterinary Advances. 7(4), 508-511. 
[23] NASCIMENTO, G. G. F.; LOCATELLI, J.; FREITAS, P. C.; SILVA, G. L.: (2000). Antibacterial activity of plant extracts and phytochemicals on antibiotic-resistant bacteria. Brazilian Journal of Microbiology. 31(4), 247-256.

Dr. Dragana Grujić; Dr. Aleksandar Savić; Dr. Ljiljana Topalić-Trivunović; Dr. Simona Jevšnik; Dr. Tatjana Rijavec; Dr. Marija Gorjanc 


\section{VLIV PLAZMOVÉ PŘÍPRAVY NA STRUKTURU A ANTIMIKROBIÁLNÍ VLASTNOSTI PLETENIN OŠETŘENÝCH BYLINNÝMI EXTRAKTY}

V tomto příspěvku byl sledován vliv plazmové prípravy na strukturu a antimikrobiální vlastnosti pletenin (100\% bavlna, 100\% bambus a 50\% bavlna / 50\% bambusu) ošetřených alkoholickými bylinnými výtažky z řebřičku obecného a křídlatky japonské. Vliv plazmové př́pravy na bázi vodní páry na povrchovou funkčnost nebo na změny struktury pletenin se hodnotí pomocí SEM. Antimikrobiální vlastnosti pletenin ošetřených bylinnými extrakty byly testovány na Escherichia coli, Staphylococcus aureus a Candida albicans za pomoci paralelní pruhovací metody (AATCC TM 147 - 2004). Stupeň zabarvení byl hodnocen metodou CIELAB a stereomikroskopem. Bylo zjištěno, že plazmová příprava a zpracování za použití bylinného výtažku z křídlatky japonské mělo pozitivní dopad na antimikrobiální ochranu pletenin proti Staphylococcus aureus.

\section{EINFLUSS DER PlASMABEHANDLUNG AUF DIE STRUKTUR UND DIE ANTIMIKROBIELLEN EIGENSCHAFTEN VON STRICKWAREN, DIE MIT KRÄUTEREXTRAKTEN BEHANDELT WURDEN}

In diesem Beitrag wurde der Einfluss von Plasmabehandlung auf die Struktur und die antimikrobiellen Eigenschaften von Strickwaren (100\% Baumwolle, 100\% Bambus, $50 \%$ Baumwolle / 50\% Bambus), die mit alkoholischen Kräuterextrakten aus Achillea millefolium L. und Reynoutria japonica Houtt behandelt wurden, untersucht. Der Einfluss der Plasmabehandlung auf Basis vom Wasserdampf auf die Oberflächenfunktionalisierung oder auf Strukturveränderungen von Strickwaren wurde mit Hilfe von SEM bewertet. Die antimikrobiellen Eigenschaften der mit Kräuterextrakten behandelten Strickwaren wurden auf Escherichia coli, Staphylococcus aureus und Candida albicans mit Hilfe des parallelen Streifenverfahrens (AATCC TM 147 - 2004) getestet. Die Menge an Verfärbung wurde mit dem CIELAB Modell und mit dem Stereomikroskop beurteilt. Man stellte fest, dass die Plasmabehandlung und die Bearbeitung mit Hilfe des Extrakts aus Reynoutria japonica Houtt. einen positiven Einfluss auf den antimikrobiellen Schutz der Strickwaren gegen den Staphylococcus aureus hatte.

\section{WPŁYW PRZYGOTOWANIA PLAZMOWEGO NA STRUKTURĘ I WŁAŚCIWOŚCI ANTYMIKROBOWE DZIANIN USZLACHETNIONYCH WYCIĄGAMI Z ZIÓŁ}

W niniejszym artykule badaniem objęto wpływ przygotowania plazmowego na strukturę i właściwości antymikrobowe dzianin (100\% bawełna, $100 \%$ bambus i $50 \%$ bawełna / $50 \%$ bambus) uszlachetnionych alkoholowymi wyciągami z ziół - krwawika pospolitego i rdestowca ostrokończystego. Wpływ przygotowania plazmowego na bazie pary wodnej na funkcje powierzchni lub zmiany struktury dzianin ocenia się przy pomocy SEM. Antymikrobowe właściwości dzianin uszlachetnionych wyciągami z ziół testowano na Escherichii coli, Staphylococcus aureus i Candida albicans przy pomocy równoległej metody paskowej (AATCC TM 147 - 2004). Stopień ubarwienia oceniano przy pomocy metody CIELAB i stereomikroskopu. Stwierdzono, że przygotowanie plazmowe i uszlachetnienie wyciągiem $\mathrm{z}$ rdestowca ostrokończytego wpłynęło pozytywnie na antymikrobową ochronę dzianin przed Staphylococcus aureus. 